\title{
The Effect of Problem Based Learning (PBL) Model toward Student's Creative Thinking and Problem Solving Ability in Senior High School
}

\author{
Roni Rohana Sihaloho ${ }^{1}$, Sahyar ${ }^{2}$, Eva Marlina Ginting ${ }^{3}$ \\ ${ }^{I}$ (Postgraduate, State University of Medan, Medan, Indonesia) \\ ${ }^{2}$ (Lecturer, State University of Medan, Medan, Indonesia) \\ ${ }^{3}$ (Lecturer, State University of Medan, Medan, Indonesia) \\ Corresponding Author: Roni Rohana Sihaloho
}

\begin{abstract}
This study aimed to analyze whether the gain of student's creative thinking and problem solving ability by using conventional learning and problem based learning model; to analyze whether the gain of creative thinking and problem solving ability of student's taught by the problem based learning (PBL) model was better than conventional learning. This study was quasi experimental research with two group pretestposttest design. The population of this research were all of sudent's of class X SMA Negeri 1 Silimakuta, Saribudolok, North Sumatera academic 2016/2017. The sample of this research were taken by using class random sampling technique consisted of two classes. Class $X-B$ was experimental class taught by problem based learning model, Class X-D was control class taught by conventional learning. The instruments of the research were valid essay test of creative thinking and problem solving ability. The data were analized by using t-test. The results showed that: the average gain of student's creative thinking and problem solving ability taught by conventional learning was in low level and the mean gain of student's creative thinking and problem solving ability taught by problem based learning model was in medium level. The average gain of student's creative thinking and problem solving ability taught by problem based learning model was better than conventional learning. There was an effect of problem based learning model on student's creative thinking and problem solving ability.
\end{abstract}

Keywords: Problem Based Learning Model, Creative Thinking Ability, Problem Solving Ability.

\section{Introduction}

Education of Indonesia in $21^{\text {st }}$ century requires learning that directs student's to think creatively, innovatively, productively, responsibly and able to contribute to society, nation, state, and world civilization. One of the Goverment real effort faces $21^{\text {st }}$ century is changing perceptions and arranging a new curriculum namely revised curriculum 2013. The objective of revised curriculum 2013 is to make student's have higher order thinking skill (HOTS). HOTS is a process of thinking not just memorize and convey information that is known. HOTS is the ability to connect, manipulate, and transform the existing knowledge and experience to creative thinking in making decisions and solving problems in new situations.

HOTS is an important thing that can be applied in the learning process, including physics learning. The implementation of high order thinking skills in learning will cause student's to be used to analyze, reason and creatively in solving problems found in daily life

Learning physics is also one of the efforts to achieve education goals that can educate the life of the nation. In the process of learning physics, student's can see directly the physics phenomenon to grow curiosity. From curiosity, student's can be motivated to learn physics. Facts found in the field, student's still have low order thinking skills. The cause is that the learning is still teacher centered, teachers centered means teachers are more active in learning. Based on the results of physics teacher interviews, learning physics in classroom still faces several problems. Learning still uses conventional and non contextual learning. Physics teachers have not been effective in teaching creative thinking and problem solving ability so that student's do not even have high order thinking skills. In the implementation of curriculum 2013, student's must participate in developing problem solving ability on the subject being studied through the problem. When student's learn something from problems, it gives student's the challenge to have high order thinking skill [1].

To overcome the problems that have been mentioned, a teacher must be able to determine how to fulfill the objectives of curriculum 2013 that student's have high order thinking skills (HOTS), namely ceative thinking ability (CTA) and problem solving ability (PSA). This is closely related to the way teacher carries out 
the learning process in the classroom. One of the ways used is choosing the right learning model, that is problem based learning model (PBL). PBL is one of learning models designed primarily to help student's develop their thinking, problem-solving and intellectual abilities, learn the roles of adults by experiencing them through simulated real situations, and become independent and autonomous learners [2]. So, PBL model is able to grow high-order thinking skill (HOTS). The essence of PBL model is learning based on problems that require authentic and real investigation [1]. Characteristics of PBL are 1) Asking questions or problems, creating questions related to the problem and enabling the emergence of various solutions to solve the problem. 2) Focusing on interdisciplinary linkages, student's review the issues from different subjects. 3) Authentic inquiry, student's must analyze, establish problems, develop hypotheses and make predictions, collect and analyze information, carry out experiments and draw conclusions. 4) Produce products and publish, demanding learners to produce certain products in form of real work or demonstrations that represent the solution of problems they find. 5) Collaboration, student's work together, most commonly forming pairs in small groups. Work together to motivate continuously in more complex assignments and improve the development of social skills [1].

The steps of PBL model according to Arends [2]: (1) orient student's to the problem; (2) Organize student's for study; (3) Assist independent and group investigations; (4) Develop and present artifacts and exhibit; (5) Analyze and evaluate the problem solving process [2]. The advantages of the PBL model is able to train student's to use various concepts, principles and skills they have learned to solve the problems that are faced as in [1]. But the disadvantage of this model is taking long time complete learning [3].

Constructive PBL models can make learners have high order thinking skills such as critical thinking, problem solving, and creative thinking as in [4]. At the end of the PBL process, it can be seen that student's can identify and solve problems with their own ideas and abilities that develop their creative thinking, one of the higher order thinking skills as in [5].

Conventional learning is more conventionally used nowadays. According to Russefendi [6] conventional learning is learning commonly used every day. In conventional learning, teachers seem to be more active as motivators of knowledge about subject matter and methods generally used are lecture methods with question and answer, demonstration, discussion and assignment so that student's are less active in getting information or concepts as learning objectives. The implementation of PBL model in learning process is important because not only trying to answer questions or solve problems, student's are also motivated to work hard. In spite of developing PSA, this approach also emphasizes the achievement of high order thinking skill namely critical, creative, and productive thinking [7]. Creative thinking ability (CTA) is thinking to create a new idea [8], while according to Hawadi [9] someone thinks creatively or diverges because he has creativity on him self. Munandar [8] states that the ability to think creatively has indicators namely fluence, flexibility, original and elaboration.

Creative thinking ability (CTA) is thinking to create a new idea [16], while according to Hawadi [12] someone thinks creatively or diverges because he has creativity him self. Munandar [16] states that the ability to think creatively has indicators namely fluence, flexibility, original and elaboration.

Some previous research have been conducted to examine the effect of PBL model on creative thinking ability and the results show that PBL learning model can enhance creative thinking ability significantly as in [34], [7], [30] and [10].

Dahar [14] defines that PSA is one of high order thinking skill because student's must have the ability to combine rules to achieve solution. In general, a problem is a situation that fulfills the following requirements: 1) The situation indicates a gap between expectations and reality, 2) The situation generates motivation to find a solution and, 3) No flash tools are available to find a way out [15]. Heller [16] states PSA steps in learning science include physics through five stages: (1) visualize the problem; (2) describe the problem in physics description; (3) plan the solution; (4) excute the plan; (5) check and evaluate. The research about the effect of PBL model on CTA shows that CTA of experimental group taught by PBL model is better than conventional group in [5] [17]. The difference of this research with the previous research is the data analyzed based on the enhancement of pretest and posttest score which is called the average gain, then PBL model simultaneously influence two dependent variable namely CTA and PSA.

\section{Method}

This research was a quasi experimental research with two group pretest-posttest design. The population of this research was second semester of class X academic year 2016/2017 at SMA Negeri 1 Silimakuta. The sample of this research were two classes that consisted of 73 student's by using class random sampling technique. Class X-B was experimental class taught by PBL model, class X-D was control class taught by conventional learning. Variables of this research consisted of independent and dependent variable. The independent variable was PBL learning model. The dependent variables were CTA and PSA. The treatment instruments were lesson plan, handout, and student workbook. Measurement instruments consisted of valid essay test of CTA and PSA that fulfilled validity and reliability requirements. The CTA indicators consisted of four, namely fluence, flexibility, original and elaboration. PSA indicators consisted of five aspects namely 
visualize the problem, describe the problem in physics description, plan the solution, excute the plan and check and evaluate. The material was essay test of temperature and heat for second semester of class $\mathrm{X}$. The data were analyzed by using prerequisite and hypothesis test. The normality test were analyzed by Kolmogorov-Smirnov Test. The homogeneity test were analyzed by Levene's Test of equality error variance. Hypothesis test were analyzed by using t-test with the level of significance 0.05 .

\section{Result}

The result of pretest and posttest data of the study by appliying PBL model on experimental group and conventional learning on control group can be seen in Table 1 .

Table 1. Pretest and posttest data

\begin{tabular}{|l|l|l|l|l|l|}
\hline Variable & Group & Pretest & Posttest & Gain & Category \\
\hline \multirow{2}{*}{ CTA } & Control & 35.00 & 55.65 & 0.30 & Low \\
\cline { 2 - 6 } & Experiment & 35.71 & 68.00 & 0.49 & Medium \\
\hline \multirow{2}{*}{ PSA } & Control & 32.82 & 53.34 & 0.31 & Low \\
\cline { 2 - 6 } & Experiment & 34.03 & 66.89 & 0.49 & Medium \\
\hline
\end{tabular}

Based on Table 1, it can be seen that the posttest of the experimental group taught by PBL model is higher than control group. The gain of experimental is in medium level. While control group taught by conventional learning is in low level. The average score of posttest answers for CTA and PSA each indicators can be seen in Table 2 and Table 3.

Table 2. The mean of student's posttest answers for each item analysis of CTA in control and experiment groups

\begin{tabular}{|l|l|c|c|}
\hline \multirow{2}{*}{ No. } & Indicators of CTA & \multicolumn{2}{|c|}{ Average Score of Item Analysis } \\
\cline { 3 - 4 } & & Control Group & Experimental Group \\
\hline 1 & Fluence & 2.71 & 2.77 \\
\hline 2 & Flexiblility & 2.55 & 2.93 \\
\hline 3 & Original & 1.58 & 2.34 \\
\hline 4 & Elaboration & 1.74 & 2.63 \\
\hline
\end{tabular}

Table 3. The mean of student's posttest answers for each item analysis of PSA in control and experiment

\begin{tabular}{|l|l|l|l|}
\hline No & Indicators of PSA & \multicolumn{2}{|c|}{ Average Score of Item Analysis } \\
\cline { 3 - 4 } & & Control Group & Experimental Group \\
\hline 1 & Understanding problem & 11.55 & 14.86 \\
\hline 2 & Interpreting problem & 11.18 & 14.57 \\
\hline 3 & Planning strategy & 10.84 & 13.49 \\
\hline 4 & Implemeting strategy & 11.58 & 13.37 \\
\hline 5 & Evaluating Solution & 8.11 & 10.60 \\
\hline
\end{tabular}

Furthermore, to measure the gain of CTA and PSA during the learning process, it is required pretest and postest data. The following formula is used to measure the value of gain:

$\langle\mathrm{g}\rangle=\frac{\left\langle\mathrm{S}_{\text {post }}\right\rangle-\left\langle\mathrm{S}_{\text {pre }}\right\rangle}{\left\langle\mathrm{S}_{\max }\right\rangle-\left\langle\mathrm{S}_{\text {pre }}\right\rangle}$

Table 4. Normalized gain score

\begin{tabular}{|l|l|}
\hline Gain Score & Category \\
\hline $0.00-0.20$ & very low \\
\hline $0.21-0.40$ & Low \\
\hline $0.41-0.60$ & medium \\
\hline $0.61-0.80$ & High \\
\hline $0.81-1.00$ & very high \\
\hline
\end{tabular}

Gain category of CTA and PSA in control and experimental group can be seen in Figure 1 and 2. 


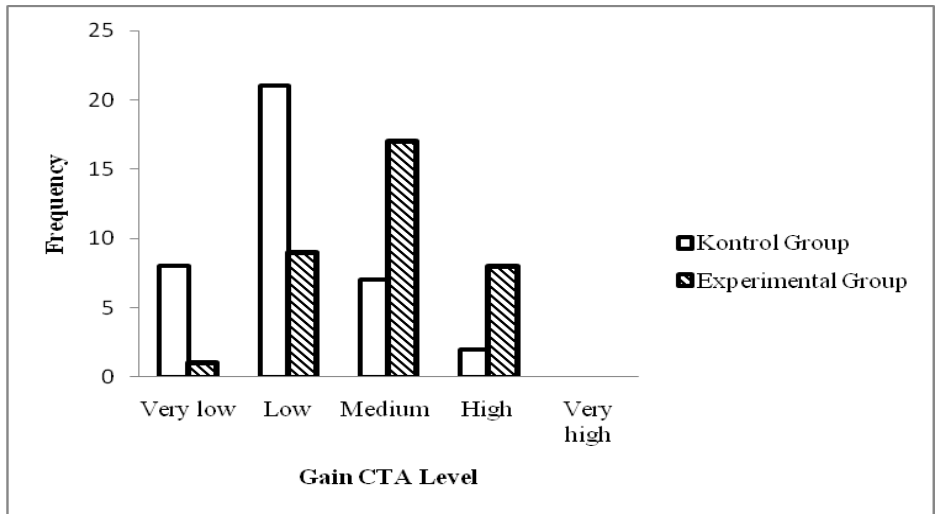

Figure 1. Gain Category of CTA in Control and Experimental Group

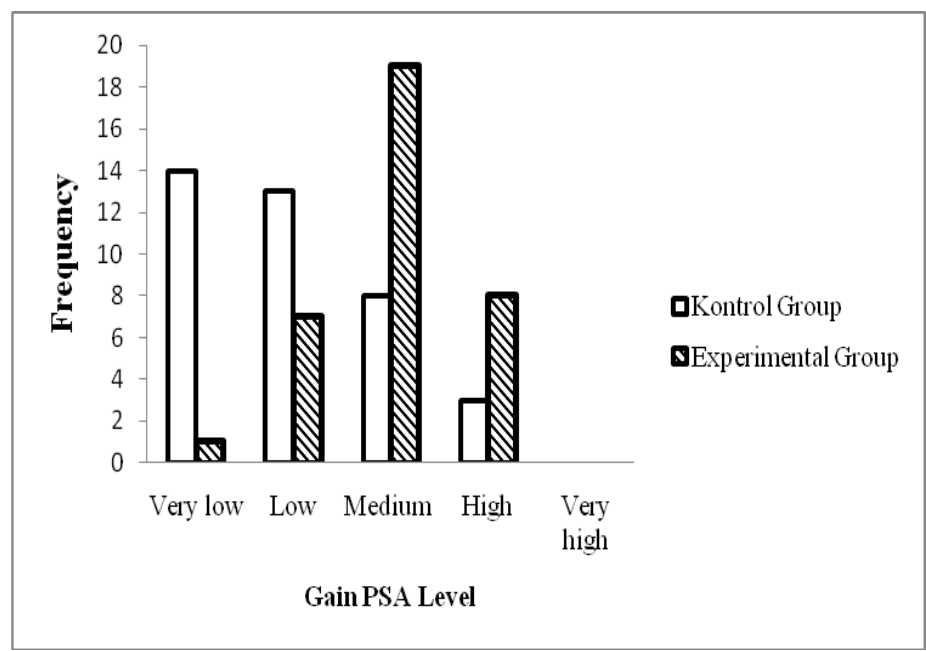

Figure 2. Gain Category of PSA in Control and Experimental Group

Based on figure 1 and figure 2, the gain of CTA and PSA of experimental group taught by PBL model is in medium level while control group taught by conventional learning is in low level. To test the hypothesis, the gain data should be tested by using normality and homogeneity test. After the gain data normal and homogeneous, will be continued by using t-test. The normality test of gain data is used to determine whether the sample comes from normally distributed population or not. Normality test of gain data is analyzed by Kolmogorov-Smirnov test. Variant homogeneity test was analyzed by levene's test of equality error variance. Hypothesis were analyzed by using t- test with significance level 0.05 with SPSS 17 program. The result of CTA prerequisite test can be seen in table 5 .

Table 5. Normality test of the gain sudents' of CTA in control and experimental group

\begin{tabular}{|l|c|c|c|}
\hline \multirow{2}{*}{ Groups } & \multicolumn{3}{|c|}{ Kolmogorov-Smirnov } \\
\cline { 2 - 4 } & Statistic & Df & Sig. \\
\hline $\begin{array}{l}\text { Gain } \\
\text { Experimental }\end{array}$ & 0.072 & 35 & $0.200^{*}$ \\
\hline Gain Control & 0.087 & 38 & $0.200^{*}$ \\
\hline
\end{tabular}

Based on table 5, the gain of CTA significance level of experimental and control group is higher than 0.05. it can be concluded that the CTA gain data of experimental and control group come from normally distributed population. Variant homogenity test was analyzed by using levene's test of equality error variant of CTA Gain data of each class can be seen in table 6.

Table 6. Two varience homogenity of CTA in experimental and control group

\begin{tabular}{|l|l|l|l|}
\hline \multicolumn{4}{|c|}{ Homogenity Test of Gain } \\
\hline Levene's Statistic & \multicolumn{1}{|c|}{ df 1 } & df 2 & \\
\hline 0.090 & 1 & 71 & 0.765 \\
\hline
\end{tabular}


Based on table 6, it can be seen that the output of CTA gain data homogenity test is significance 0.765 higher than 0.05. So, it can be concluded that the gain data of the two groups has the same variant. Furthermore, the PSA gain normality and homogenity test can be seen in table 7 and table 8 .

Table 7. Normality test of the gain sudent's of PSA in control and experimental group

\begin{tabular}{|l|l|l|l|}
\hline \multirow{2}{*}{ Groups } & \multicolumn{3}{|c|}{ Kolmogorov-Smirnov } \\
\cline { 2 - 4 } & Statistic & Df & Significance \\
\hline Experimental & 0.093 & 35 & $0.200^{*}$ \\
\hline Control & 0.090 & 38 & $0.200^{*}$ \\
\hline
\end{tabular}

Based on table 7, the gain of PSA significance level of experimental and control group is higher than 0.05. it can be concluded that the PSA gain data of experimental and control group come from normally distributed population.

Table 8. Two varience homogenity of PSA in experimental and control group

\begin{tabular}{|c|l|l|c|}
\hline \multicolumn{4}{|c|}{ Homogeneity Test of Gain } \\
\hline Levene's Statistic & \multicolumn{1}{|c|}{ df $\mathbf{1}$} & df 2 & Sig \\
\hline 0.114 & 1 & 71 & 0.737 \\
\hline
\end{tabular}

Based on table 8 , it can be seen that the output of PSA gain homogenity test is significance 0.737 higher than 0.05. So, it can be concluded that the PSA gain of the two groups has the same variant. Hypothesis testing is done after the requirements of data feasibility test is completed and fulfilled, then hypothesis testing is done by using Independent Sample T-Test with the help of SPSS 17 program. The statistic output of CTA and PSA t-test can be seen in table 9 and table 10.

Table 9. T-Test gain of CTA

\begin{tabular}{|c|c|c|c|}
\hline Output & T & df & Significance. (2-tailed) \\
\hline Gain CTA & 5.143 & 71 & 0.000 \\
\hline
\end{tabular}

Based on Table 9, it can be seen that significance level ( $\mathrm{sig})<0,05$ is 0.000 so $\mathrm{H}_{0}$ is rejected. It can be concluded that CTA gain of students taught by PBL model is better than conventional learning in learning physics.

Table 10. T-Test gain of PSA

\begin{tabular}{|c|c|c|c|}
\hline Output & T & df & Significance. (2-tailed) \\
\hline Gain PSA & 4.888 & 71 & 0.000 \\
\hline
\end{tabular}

Based on Table 10, it can be seen that the significance level ( $\mathrm{sig})<0,05$ is 0,000 so $\mathrm{H}_{0}$ is rejected. So, it can be concluded that PSA gain of students taught by PBL model is better than conventional learning in learning physics. This is in line with the output of descriptive analysis that shows that the average gain of experimental group is higher than the control group.

\section{Discussion}

\subsection{The Average Gain of Students' Creative Thinking Ability Taught by PBL Model Was Better than Conventional Learning.}

The findings of this study showed that the average gain of student's creative thinking ability taught by PBL model was better than conventional learning.

Student's who were taught by PBL model had better CTA gain. This is in line with the research [13], [19], [10] and [20]. CTA gain was better because PBL activities tend to invite student's to learn more actively. Besides PBL helps student's to develop PSA in discussion activities where they make student's work in teams, design inquiry to solve the problems, propose solutions, find ideas, and develop ideas in solving problems so that student's CTA to generate creative ideas enhanced. Student's interacted socially with other friends in the discussion to trigger the formation of new ideas and enrich their intellectual development. Student's become 
highly motivated because they treated problem as their own. Student's involved more in learning and become more creative.

While in conventional group, student's learned from the teacher and less faced with problems that encouraged student's to develop their own understanding. In addition, the exchange of ideas between student's in conventional group was less effective because teacher took greater role in learning process.

The advantages of PBL model to enhance creative thinking ability can be seen from PBL steps. There are five steps of PBL model, namely (1) Orient student's to the problem; (2) Organize student's for study; (3) Assist independent and group investigations; (4) Develop and present artifacts and exhibit; (5) Analyze and evaluate the problem solving process. Evaluation with authentic assessment carried out in each steps [2]. Based on these steps, it clearly showed that student's played more active role in learning process.

The first step was problem orientation. This step allowed student's to convey ideas to develop thinking smoothly ability. Thinking smoothly is the ability to convey or answer some ideas, smoothly.

The second step was organizing student's in learning. It provided space for student's to collaborate in investigating problems. Activities done by members in groups discussion developed creative thinking ability that included indicators of smooth and flexible thinking. Group discussions and debates enhanced high order creative thinking ability and knowledge construction.

The third steps was providing assistance in self-investigation or groups to solve the problem in order to build their own knowledge (constructivism). The activity to design own experiments in order to test the hypothesis can enhance the ability to make details. The ability to make details was creative thinking ability by explaining steps more detail. Experimental design activities encouraged student's to think about the tools and materials needed, steps and how to tabulate the data obtained. This was in line with the research [9] that PBL model affected thinking in detail.

The fourth steps was developing or presenting the output. The experiment design developed by student's was output. It reflected original thinking ability, student's developed through designing their own experiments. Experimental designs created by student's in learning process enhanced self confidence about the results of their own thinking, so student's were not tending to find the same answer with other groups or books to reinforce their confidence in their original design. Original thinking ability reflected student's attitudes after listening ideas and then working to find a new solution. Novelty was not absolute at something completely new that had never before but can be different from others or combination of things that already existed. Munandar [8] stated that original thinkers are student's who can gave unusual answers, others from others, rarely given by most people at the same level of knowledge.

The fifth stage was evaluating the solution. This activity used to help student's analyze and evaluate their thinking processes from investigation to the implementation and realization of solutions. In this stage, student's expressed ideas and mindsets used to find solutions. Expressing ideas enhanced smooth, flexible, and detail thinking ability. The results of investigation obtained through practicum activities were presented. Student's made presentations as attractive as possible, clear and easily understood by other student's. Student's work was presented in class.

From the stages above, it can be concluded that PBL model can enhance student's CTA gain. This was in line with [10], [12], [13], [21] and [20]. However, this study did not measure the gain of CTA for each student. [13] argued that PBL model enhanced student's creative thinking ability and the result was student's were able to identify and solve problems with their own ideas and creative thinking. The Ersoy study did not use a normalized gain analysis.

This study was in line with research [10], [22] concluded that each indicator of creative thinking ability was enhanced after applying PBL model. Student's taught by PBL model had better CTA than conventional learning. This research had not seen the effect of CTA and PSA influenced by PBL model with two variables simultaneously.

From the explanation and the results of the research above, it can be concluded that there was gain of CTA between student's taught by PBL model and it was better than conventional learning.

\subsection{The Average Gain of Students' Problem Solving Ability Taught by PBL Model Was Better than Conventional Learning.}

The findings of this study showed that the average gain of student's problem solving ability taught by PBL model was better than conventional learning. The PSA gain of student's taught by the PBL model is in medium level. The PSA gain of student's taught by conventional learning is in low level. This showed that the PSA gain of student's taught by PBL model was better than conventional learning.

It caused by PBL model that was characterized by the problems encountered in everyday life then, student's widen their knowledge about what was known and how to solve problems in groups and collaborate each other in solving problems. When student's solved problems based on real events, they involved their 
thinking. Student's who were active in solving problem meant that PSA developed. PBL model can foster PSA. Teachers educated and trained student's to be proficient in solving problems with the five indicators. Teachers should provide motivation and trained systematic PSA of student's [2].

This was in line with Dwi [23] stated that PBL model enhanced student's PSA of physics problems. Furthermore, Sahyar and Fitri [5] and Sahyar and Malau [17], showed that the average gain of posttest score of experimental group taught by PBL model was better than the control group taught by conventional learning. In accordance with the study of Destianingsih [11] showed that there was an effect of PBL on student's PSA in learning physics. This study were different with [23], [5], [17] and [11] as they only used pretest and postest scores and did not use normalized gain analysis.

Furthermore, from posttest score, student's taught by PBL model had higher score than the conventional learning. This was due to the PBL process characterized by the problems encountered in daily life, then student's widen their knowledge of what was known and how to collaborate in groups to solve problems. In line with [9] stated that learning approach used real problems as a context to learn PSA and acquired essential knowledge and concepts. This allowed student's to exchange ideas, work together to solve problems that can ultimately enhanced student's physics PSA. In line Temel, Senar [24] stated that PBL model had positive effect on student's PSA thinking and perceptions. Moreover, teacher introduced different model from conventional learning where the involvement in learning was unknown as a reason for low level of thinking ability, but in this process teachers were given the opportunity to develop student's PSA in thinking and perception.

The advantages of PBL model that enhanced student's PSA can be seen from the steps. There were five steps of PBL model namely (1) orientation of problems, (2) organizing student's to do research, (3) providing assistance in independent or group investigation, (4) developing and presenting the results, and (5) analyzing and evaluating the problem-solving process. Based on these steps, it was clear that student's played active role in learning process. As stated by Goddess [25], it was clear that student's were more active in learning process which took place in the third and fourth steps, student's used their CTA and PSA to solve problems faced, and in the last steps, student's were given a small test in form of quiz to find out whether student's were able to understand learning well.

The enhancement of PSA by using PBL model caused by 1) student's were challenged by the submission of contextual problems at the beginning of learning, 2) Interaction with group members allowed student's had turn to share information when they tried to solve problem then indirectly PBL model implemented and enhanced good communication among student's [26]; 3) student's tried to ask and discuss with friends and teachers [7], 4) through the process of observing, questioning, gathering information and communicating, the student's built knowledge with experience and prior knowledge 17,5) this model stimulated the development of student's CTA 6) teachers motivated and trained student's PSA systematically [27].

Based on the explanation above, it was clear that the PBL model can enhance student's PSA in learning physics. This was due to the conventional learning, teacher conveyed information directly to student's by setting the time to achieve defined goals as efficiently as possible [28]. So, teacher centered learning reduced student's opportunity to develop PSA.

\section{Conclusions}

Based on the results of analysis and discussion, it was obtained some conclusions as the following:

Based on the results of analysis and discussion, it was obtained some conclusions as the following:

1. The gain of student's CTA and PSA taught by conventional learning was in low level.

2. The gain of student's CTA and PSA taught by problem based learning model was in medium level. There was significant effect of problem based learning model on student's CTA and PSA in learning physics.

3. The gain of student's CTA and PSA taught by PBL model was better than conventional learning. It showed that the PBL model had better effect on student's CTA and PSA.

\section{REFERENCES}

[1] Tan, Oon Seng. 2009. Problem Based Learning And Creativity. National Institute of Education, Nanyang Technological University, Singapore.

[2] Arends, Richard. 2013. E-book Learning To Teach.

[3] Fakhriyah, F. 2014. Penerapan Problem Based Learning dalam Upaya Mengembangkan Kemampuan Berpikir Kritis Mahasiswa.Jurnal Pendidikan IPA Indonesia, 3 (1) : 95-101.

[4] Ersoy, E., Baser, N. 2014. The Effects of Problem Based Learning Method in Higer Education on Creative Thinking. Procedia Social and Behavioral Science, 116 : 3494-3498.

[5] Sahyar, Fitri, R.K. 2017. The Effect of Problem-Based Learning Model (PBL) and Adversity Quotient (AQ) on Problem Solving Ability. American Journal of Educational Research, 5 (2) : 179-183. 
The Effect of Problem Based Learning (PBL) Model toward Student's Creative Thinking and...

[6] Ruseffendi, E. T. 1991. Pengantar Kepada Membantu Guru Mengembangkan Kompetensinya dan

Pengajaran Matema-tika untuk Meningkatkan CBSA. Bandung: Tarsito

[7] Sagala,S. 2011. Konsep dan Makna Pembelajaran. Bandung: Alfabeta.

[8] Munandar, Utami. 1999. Pengembangan Kreativitas Anak Berbakat. Jakarta : Rineka Cipta.

[9] Hawadi, R.A., S.D. Wihardjo., \& M. Wiyono. 2001. Kreativitas. Jakarta : PT Grasindo.

[10] Wahyu,W dan Rohaeni Nur Eli. 2016. Using Problem Based Learning to Improve Student's Creative Thinking Skills on Water Purification. AIP Conference Proceedings 1708, 040008

[11] Destianingsih, E, Abidin Pasaribu dan Ismet. 2015. Pengaruh Model Problem Based Learning terhadap Kemampuan Pemecahan Masalah Siswa pada Pembelajaran Fisika Kelas XI di Sma. Universitas sriwijaya. Inovasi dan Pembelajaran Fisika ISSN: 2355 - 7109

[12] Talens, Joy. 2016. Influence of Problem Based Learning on the Creative Thinking Skills of Physical Science Student's of De La Salle Lipa. Journal of Education, Arts and Sciences vol. 02 no. 0115.

[13] Ersoy, E., Baser, N. 2014. The Effects of Problem Based Learning Method in Higer Education on Creative Thinking. Procedia Social and Behavioral Science, 116 : 3494-3498.

[14] Dahar, R.W. 1996. Teori-Teori Belajar, Jakarta : Erlangga

[15] Petrina, S. 2007. Advanced Teaching Methods for The Technology Classroom. Canada: Information Science Publishing.

[16] Heller, P., Ronald, K., \& SCOTT,A. 1991. Teaching Problem Solving Through Cooperative Group.

[17] Sahyar, Sani, R.A.\& Malau, T. 2017. The Effect of Problem Based Learning (PBL) Model and Self Regulated Learning (SRL) toward Physics Problem Solving Ability (PSA) of Student's at Senior High School. American Journal of Educational Research, 5 (3) : 279-283.

[18] Hake.1998. Interactive Engagement Vs Traditional Methods: A Six Thousand Student Survey of Mechanics Test Data for Introductory Physics Courses. Am. J. Phys. 66, 64 -74.

[19] Talens, Joy. 2016. Influence of Problem Based Learning on the Creative Thinking Skills of Physical Science Student's of De La Salle Lipa. Journal of Education, Arts and Sciences vol. 02 no. 0115.

[20] Yulianingtias H, Vanny m.a. Tiwow dan Anang W. M. Diah. 2016. Pengaruh Model Problem Based Learning (PBL) terhadap Keterampilan Berpikir Kreatif dan Hasil Belajar Siswa Pelajaran IPA Kelas VII SMP Negeri 3 Palu. e-Jurnal Mitra Sains, Volume 4 Nomor 2,hlm 62-70 ISSN: 2302-2027

[21] Awang, H, dan Ishak Ramly. 2008. Creative Thinking Skill Approach Through Problem-Based Learning: Pedagogy and Practice in the Engineering Classroom. World Academy of Science, Engineering and Technology International. Journal of Social, Behavioral, Educational, Economic, Business and Industrial Engineering Vol:2, No:4

[22] Orozco, J dan Rosanelia T. 2016. Problem Based Learning: Effects on Critical and Creative Thinking Skills in Biology. Asian Journal of Biology Education Vol. 9.

[23] Dwi, I, H. Arif dan K. Sento. 2013. Pengaruh Strategi Problem Based Learning berbasis ICT terhadap Pemahaman Konsep dan Kemampuan Pemecahan Masalah Fisika. Jurnal Pendidikan Fisika Indonesia 8-17. ISSN: 1693-1246

[24] Temel, Senar. 2014. The Effects of Problem Based Learning on Pre-Service Teachers' Critical Thinking Dispositions and Perceptions of Problem Solving Ability. South African Journal of Education, 5(3): 155-165.

[25] Dewi, P. S. U. 2014. Pengaruh Model Based Learning terhadap Kemampuan Pemecahan Masalah Fisika melalui Pengendalian Bakat Numerik Siswa SMP. e-Journal Program Pascasarjana Universitas Pendidikan Ganesha Program Studi IPA,4 (1):10-19.

[26] Surif, Johari, Nor Hasniza Ibrahim and Mahani Mokhtar. 2013. Implementation of Problem Based Learning in Higher Education Institutions and Its Impact on Student's Learning. The 4th International Research Symposium on Problem Based Learning (IRSPBL), Universiti Teknologi Malaysia, Johor Bahru 81310, Malaysia.

[27] Ogunleye, A.O. 2009. Teachers and Student's Perceptions of student's Problem Solving Difficulties in Physics: Implications for Remidiation. Asian Journal of Biology Education Vol. 9.

[28] Slavin, R. E. 2008. Psikologi Pendidikan (Teori \& Praktik). Edisi Kedelapan. Jakarta : PT. Indeks.

Roni Rohana Sihaloho. "The Effect Of Problem Based Learning (PBL) Model On senior High School Students' Creative Thinking And Problem Solving Ability Of Physics Problems." IOSR Journal of Research \& Method in Education (IOSR-JRME) 7.4 (2017): 11-18. 